\title{
Production responses of Holstein dairy cows when fed supplemental fat containing saturated free fatty acids: a meta-analysis
}

\author{
Wenping Hu${ }^{1, *}$, Jacquelyn P. Boerman ${ }^{1}$, and James M. Aldrich ${ }^{1}$
}

* Corresponding Author: Wenping Hu Tel: +1-937-770-2400, Fax: +1-937-770-2494,

E-mail:whu@provimi-na.com

'Nurture Research Center, Provimi, Brookville, $\mathrm{OH}$ 45309, USA

Submitted Aug 16, 2016; Revised Jan 15, 2017; Accepted Feb 1, 2017
Objective: A meta-analysis was conducted to evaluate the effects of supplemental fat containing saturated free fatty acids (FA) on milk performance of Holstein dairy cows.

Methods: A database was developed from 21 studies published between 1991 and 2016 that included 502 dairy cows and a total of 29 to 30 comparisons between dietary treatment and control without fat supplementation. Only saturated free FA ( $>80 \%$ of total FA) was considered as the supplemental fat. Concentration of the supplemental fat was not higher than $3.5 \%$ of diet dry matter (DM). Dairy cows were offered total mixed ration, and fed individually. Statistical analysis was conducted using random- or mixed-effects models with Metafor package in R. Results: Sub-group analysis showed that there were no differences in studies between randomized block design and Latin square/crossover design for dry matter intake (DMI) and milk production responses to the supplemental fat (all response variables, $\mathrm{p} \geq 0.344$ ). The supplemental fat across all studies improved milk yield, milk fat concentration and yield, and milk protein yield by $1.684 \mathrm{~kg} / \mathrm{d}(\mathrm{p}<0.001), 0.095$ percent unit $(\mathrm{p}=0.003), 0.072 \mathrm{~kg} / \mathrm{d}(\mathrm{p}<0.001)$, and 0.036 $\mathrm{kg} / \mathrm{d}(\mathrm{p}<0.001)$, respectively, but tended to decrease milk protein concentration (mean difference $=-0.022$ percent unit; $\mathrm{p}=0.063$ ) while DMI (mean difference $=0.061 \mathrm{~kg} / \mathrm{d} ; \mathrm{p}=0.768$ ) remained unchanged. The assessment of heterogeneity suggested that no substantial heterogeneity occurred among all studies for DMI and milk production responses to the supplemental fat (all response variables, $I^{2} \leq 24.1 \%$; $\mathrm{p} \geq 0.166$ ).

Conclusion: The effects of saturated free FA were quantitatively evaluated. Higher milk production and yields of milk fat and protein, with DMI remaining unchanged, indicated that saturated free FA, supplemented at $\leq 3.5 \%$ dietary DM from commercially available fat sources, likely improved the efficiency of milk production. Nevertheless, more studies are needed to assess the variation of production responses to different saturated free FA, either C16:0 or C18:0 alone, or in combination with potentially optimal ratio, when supplemented in dairy cow diets.

Keywords: Fatty Acids; Performance; Dairy Cows

\section{INTRODUCTION}

Supplementing fat in dairy rations to increase energy density has been extensively evaluated in numerous studies over the last a few decades. However, it was evident that production responses to the supplemental fat varied considerably. Many factors might contribute to the various responses, with one of them being the different fat sources fed to dairy cows. There is a growing interest in understanding the effects of different fat sources, specifically saturated free fatty acids (FA) on milk production and components [1]. In particular, effects of palmitic (C16:0) or stearic acid (C18:0) as sole saturated free FA have been evaluated in recent studies [2-4].

Some meta-analysis have reviewed effects of fat addition to dairy cow diets on milk production and components [5-7]. In those meta-analyses several types of fat sources have been categorized, of which selected hydrolyzed tallow FA [5] or prilled fat [6,7] was identified as a type of fat sources 
differentiating it from others such as calcium salts, tallows, etc. However, the selected hydrolyzed tallow FA or prilled fat examined either had limited data as a fat type for the analysis, or were comprised of two different forms of saturated fat - free FA and triglyceride. The digestibility of fat supplements varies greatly by different types/forms of fat sources. For instance, much higher true digestibility was observed for hydrolyzed tallow FA [8] compared to partially hydrogenated tallow containing triglycerides ( $79 \%$ vs $43 \%$ ). Therefore, response to saturated free FA, rather than saturated fat including both free FA and triglyceride, when supplemented in diets of dairy cows needs to be specified.

Analyses reported herein were based on data collated from studies of Holstein dairy cows supplemented saturated free FA from commercially available fat sources. The objective of the metaanalysis was to evaluate the effects of supplementing saturated free FA on milk performance of Holstein dairy cows.

\section{MATERIALS AND METHODS}

\section{Database}

A thorough literature search via several major electronic database (PubMed, Google Scholar, and ScienceDirect, etc.) and review of citations of found publications was conducted based on a series of criteria developed by the authors. Studies were published with full manuscripts in English, peer-reviewed journals from 1991 to 2016. Twenty-one studies [1-4, 9-25] were thus identified for use. They reported results of effects of supplemental fat containing saturated free FA from the fat sources of industrial companies on milk performance of Holstein dairy cows. The measures of variance for all continuous variables were reported. All fat sources were considered products commercially available, even though a few of them were listed only as FA supplements (Table 1) without commercial brand names shown on the original studies $[2,9,25]$. Only saturated free FA ( $>80 \%$ of total FA) was considered as the

Table 1. Brief summary of studies included in the database

\begin{tabular}{|c|c|c|c|c|c|c|c|c|c|c|}
\hline \multirow{2}{*}{$\begin{array}{r}\text { Study } \\
\text { No. }\end{array}$} & \multirow{2}{*}{ Study design } & \multirow{2}{*}{$\begin{array}{l}\text { No. of } \\
\text { cow }\end{array}$} & \multicolumn{2}{|c|}{ FA fed $(\%)^{1)}$} & \multirow{2}{*}{ Replaced } & \multirow{2}{*}{ FA } & \multirow{2}{*}{ FA source ${ }^{2)}$} & \multirow{2}{*}{$\begin{array}{l}\text { Start of treatment } \\
\text { (day in milk) }\end{array}$} & \multirow{2}{*}{$\begin{array}{l}\text { Feeding } \\
\text { length (d) }\end{array}$} & \multirow{2}{*}{ Reference } \\
\hline & & & Control & Treatment & & & & & & \\
\hline \multirow[t]{2}{*}{1} & RBD & 12 & 0 & 3.0 & SG and ALH $(\downarrow), S B M(\uparrow)$ & C16:0/C18:0 & EB 100 & 80 & 56 & [12] - 1 \\
\hline & RBD & 12 & 0 & 3.0 & SG and ALH $(\downarrow)$, SBM $(\uparrow)$ & C16:0/C18:0 & EB 100 & 80 & 56 & [12] - 2 \\
\hline \multirow[t]{2}{*}{2} & Latin square & 4 & 0 & 2.5 & $S G(\downarrow)$ & C16:0/C18:0 & $\mathrm{EB}$ & 101 & 14 & [13] - 1 \\
\hline & Latin square & 4 & 0 & 2.5 & $S G(\downarrow)$ & $\mathrm{C} 16: 0 / \mathrm{C} 18: 0$ & $\mathrm{~EB}$ & 101 & 14 & [13] - 2 \\
\hline \multirow[t]{2}{*}{3} & Latin square & 24 & 0 & 1.5 & Soyhull $(\downarrow)$ & $\mathrm{C} 16: 0$ & BergaFat F100 & 182 & 21 & {$[4]-1$} \\
\hline & Latin square & 24 & 0 & 1.5 & $\operatorname{Corn}(\downarrow)$ & C16:0 & BergaFat F100 & 182 & 21 & [4] - 2 \\
\hline 4 & Latin square & 5 & 0 & 2.0 & $\operatorname{Corn}(\downarrow)$, SBM $(\uparrow)$ & $\mathrm{C} 16: 0 / C 18: 0$ & FA supplement (CBP) & 112 & 28 & [9] \\
\hline 5 & Latin square & 12 & 0 & 3.0 & Corn $(\downarrow)$ & $\mathrm{C} 16: 0$ & Energizer RP-10 & 26 & 21 & {$[20]$} \\
\hline \multirow[t]{2}{*}{6} & Latin square & 8 & 0 & 2.5 & Rice hull ( $\downarrow)$ & C16:0/C18:0 & EB 100 & 77 & 21 & [15] - 1 \\
\hline & Latin square & 8 & 0 & 2.5 & Rice hull ( $\downarrow)$ & C16:0/C18:0 & EB 100 & 106 & 21 & [15] - 2 \\
\hline 7 & Crossover & 16 & 0 & 2.0 & Soyhull $(\downarrow)$ & $\mathrm{C} 16: 0$ & BergaFat F100 & 249 & 21 & [1] \\
\hline 8 & $\mathrm{RBD}$ & 28 & 0 & $230 \mathrm{~g} / \mathrm{d}$ & Top dressed ${ }^{3)}$ & $\mathrm{C} 16: 0 / \mathrm{C} 18: 0$ & EB 100 & 21 days prepartum ${ }^{4)}$ & 121 & [16] \\
\hline 9 & $\mathrm{RBD}$ & 27 & 0 & $230 \mathrm{~g} / \mathrm{d}$ & Top dressed & C16:0/C18:0 & EB 100 & 21 days prepartum & 42 & [17] \\
\hline 10 & Latin square & 18 & 0 & $500 \mathrm{~g} / \mathrm{d}$ & Added to TMR & $\mathrm{C} 16: 0$ & Energizer RP-10 & 146 & 16 & [18] \\
\hline 11 & Crossover & 32 & 0 & 2.0 & 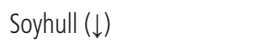 & $\mathrm{C} 16: 0$ & FA (C16:0) supplement & 151 & 21 & [25] \\
\hline 12 & Crossover & 32 & 0 & 2.0 & Soyhull $(\downarrow)$ & C18:0 & FA (C18:0) supplement & 142 & 21 & {$[2]$} \\
\hline \multirow[t]{2}{*}{13} & $\mathrm{RBD}$ & 24 & 0 & 2.0 & Soyhull $(\downarrow)$ & $\mathrm{C} 16: 0 / C 18: 0$ & EB 100 & 1 & 29 & [3] - 1 \\
\hline & $\mathrm{RBD}$ & 24 & 0 & 2.0 & Soyhull $(\downarrow)$ & $\mathrm{C} 16: 0 / \mathrm{C} 18: 0$ & EB 100 & 1 & 29 & [3] - 2 \\
\hline 14 & Latin square & 4 & 0 & 3.5 & $\operatorname{Corn}(\downarrow), \operatorname{SBM}(\uparrow)$ & C16:0/C18:0 & EB 100 Advance & 165 & 14 & {$[19]$} \\
\hline \multirow[t]{2}{*}{15} & Latin square & 12 & 0 & 1.9 & $\mathrm{CS}$ and grain mix $(\downarrow)$ & $\mathrm{C} 16: 0$ & BergaFat F100 & 211 & 21 & {$[24]-1$} \\
\hline & Latin square & 12 & 0 & 1.9 & $\mathrm{CS}$ and grain mix $(\downarrow)$ & C16:0 & BergaFat F100 & 196 & 21 & {$[24]-2$} \\
\hline \multirow[t]{2}{*}{16} & $\mathrm{RBD}$ & 16 & 0 & 2.5 & SG and ALH $(\downarrow)$ & $\mathrm{C} 16: 0 / C 18: 0$ & EB 100 & 85 & 56 & [14] - 1 \\
\hline & $\mathrm{RBD}$ & 16 & 0 & 2.5 & SG and $A L H(\downarrow)$ & C16:0/C18:0 & EB 100 & 85 & 56 & {$[14]-2$} \\
\hline \multirow[t]{2}{*}{17} & $\mathrm{RBD}$ & 32 & 0 & 1.5 & $\operatorname{Corn}(\downarrow), \operatorname{SBM}(\uparrow)$ & C16:0/C18:0 & EB 100 & 184 & 63 & [23] - 1 \\
\hline & $\mathrm{RBD}$ & 32 & 0 & 3.0 & $\operatorname{Corn}(\downarrow), \operatorname{SBM}(\uparrow)$ & C16:0/C18:0 & EB 100 & 184 & 63 & {$[23]-2$} \\
\hline \multirow[t]{2}{*}{18} & $\mathrm{RBD}$ & 36 & 0 & 2.3 & Corn $(\downarrow)$, SBM/SBH $(\uparrow)$ & C16:0/C18:0 & EB 100 & 21 & 105 & {$[21]-1$} \\
\hline & RBD & 36 & 0 & 2.3 & Corn $(\downarrow)$, SBM/SBH $(\uparrow)$ & C16:0/C18:0 & EB 100 & 21 & 105 & [21] - 2 \\
\hline 19 & Latin square & 8 & 0 & 3.0 & $\operatorname{Corn}(\downarrow), \operatorname{SBM}(\uparrow)$ & $\mathrm{C} 16: 0 / \mathrm{C} 18: 0$ & EB 100 & 126 & 21 & [22] \\
\hline 20 & $\mathrm{RBD}$ & 12 & 0 & 2.5 & Added to TMR & C16:0/C18:0 & $\mathrm{EB}$ & 92 & 72 & {$[10]$} \\
\hline 21 & $\mathrm{RBD}$ & 12 & 0 & 2.2 & Added to TMR & C16:0/C18:0 & $\mathrm{EB}$ & 50 & 75 & [11] \\
\hline
\end{tabular}

FA, fatty acid; RBD, randomized block design; SG, sorghum grain; ALH, alfalfa hay; SBM, soybean meal; SBH, soybean hull; CS, corn silage; EB, energy booster; TMR, total mixed ration.

1) \% of supplemental FA fed in the diet at DM basis unless otherwise specified.

2) EB, Milk Specialties Co., USA; BergaFat F100, Berg+Schmidt, Germany; FA supplement (CBP), CBP Resources, Inc., USA; Energizer RP-10, IFFC0, Malaysia; FA (C16:0 or C18:0) supplement, Emery Oleochemicals, Malaysia.

3) Top dressed $=$ fed on top of the TMR, $\uparrow=$ increased, $\downarrow=$ decreased.

4) Twenty-one days before expected prepartum, at 256 day of pregnancy. 
supplemental fat. Therefore, data from studies with other type of supplemental fat (e.g., Ca-salt, hydrogenated triglyceride) were excluded. Concentrations of the supplemental fat higher than $3.5 \%$ of diet dry matter (DM) in the studies were not used, in order to prevent too high concentration of fat in the diet resulted from the supplemental fat. Data [26] on dairy cows, other than Holstein breed were omitted. Cows were offered total mixed ration, and fed individually. The study [27] in which a large number of cows were fed in group on a commercial dairy farm, was thus excluded.

Two studies [16,17] were not excluded, even though there were only the studies in which the dietary treatments were applied in the transition cows before lactation (256 days of pregnancy). The whole experimental periods starting at 256 days of pregnancy in the studies $[16,17]$ were counted as the length of feeding the supplemental fat (Table 1). Nevertheless, Moallem et al [16] measured dry matter intake (DMI) prepartum and postpartum, with only the measured DMI values postpartum being used. Most dietary composition information was directly extracted from the tables of ingredient and chemical composition of diets in the original studies. A few records were incomplete or not reported uniformly, which necessitated the following assumptions and calculations. Total FA content of the diet was estimated as $\mathrm{FA}=$ ether extract-1 [8], if the content of ether extract in the diets was reported in the studies. Total long-chain FA were reported in diets of two studies [21,22], and were approximately considered as total FA in the diets. Mosley et al [18] specified that milk true protein was measured; however, the remainder reported only milk protein. In the absence of detailed information in the original references, milk protein was considered to be milk crude protein (CP) including total nitrogen content of milk, milk true protein was thus estimated to milk protein based on that non-protein nitrogen represents approximately $6 \%$ on average of the total nitrogen in milk.

Dietary treatments consisted of a basal diet as control and the control with the supplemental fat as treatment diet. The comparison between treatment and control groups was obtained from each of studies. There was only one control group in two studies $[4,23]$; however, two independent comparisons of dietary treatments to the same control group were constructed since the variance inflation effect resulted from two repeated comparisons with a single control group would be trivial [6].

\section{Statistical analysis}

All dependent variables in each individual study were weighted by the reciprocal of their corresponding squared standard error (SE). Because SE for DMI was exceptionally low in a couple of studies $[16,23]$, the SE were set to only half of the mean SE across all studies in order to prevent overweighting of the DMI data [28]. Difference was calculated as treatment - control. Effect size can be calculated as mean difference (MD), or as standardized MD in which the difference was standardized using the standard devi- ation of treatment and control groups. MD, simply allowing effect size interpretation in the original units of measurements, would be easily used to judge the magnitude of effect. In addition, the measurements of outcomes in all studies could be scaled at the same way, or transformed uniformly across all studies. The standardization of MD would not be necessary. Moreover, the use of standardized MD in meta-analysis is debatable $[29,30]$. Therefore, MD was only calculated and reported in current meta-analysis to summarize the effect size of the supplemental fat, even though the metafor package [31] provides the escalc function for calculating various effect sizes including MD and standardized MD.

Supplemental fat effects were tested separately for randomized block design (RBD) studies or Latin square/crossover design studies, or all studies including RBD and Latin square/crossover design using random-effects model. The $\mathrm{MD}$ and its $95 \%$ confidence interval (CI) and statistical significance were estimated. The random-effects models were extended to mixed-effects models [31] by including study design, i.e., RBD vs Latin square/crossover design, as a fixed categorical effect; hence the influence of study design on effect of the supplemental fat was examined. Heterogeneity of response variables among RBD or Latin square/crossover studies or all studies across both study designs were assessed with Cochran's Q-test. The heterogeneity was also quantified using the $I^{2}$ statistic. $I^{2}$ lies between 0 and $100 \%$, with a value of $>50 \%$ indicating considerably high heterogeneity [32].

As similar to the evaluation of the effect of study design (RBD vs Latin square/crossover design), supplemental fat effects were tested separately for two different FA groups, i.e., a mixture of C16:0 and C18:0 vs single FA containing C16:0 or C18:0 using random-effects model [31]. Meta-regression was conducted using mixed-effects model in full database including all studies to investigate factors which might have influences on DMI and milk production responses. This was done by screening individual factor using a p-value of $\leq 0.20$, retained factors were then subjected to backward, stepwise meta-regression until all remaining factors achieved a significant level of $\leq 0.05$ [6]. Some factors such as contents of starch and nonfiber carbohydrates in diets, etc., were important deserving investigation, but no sufficient data were available for conducting analysis. The major factors evaluated were: $\mathrm{CP}$ (\% of DM), neutral detergent fiber (NDF, \% of $\mathrm{DM}$ ), and FA (\% of DM) in control diet, length of feeding the supplemental fat (day), day in milk at start of dietary treatments (day), and difference of total FA contents (\% of DM) in diets between treatment and control. The presence of publication bias of response variables in the full database was investigated using funnel plots. The funnel plots were constructed of MD estimates from all individual studies against each corresponding study's SE. Moreover, the publication bias in the full database were assessed using Egger's regression test for funnel plot asymmetry [31].

Significance was declared at $\mathrm{p} \leq 0.05$ with tendencies accepted if $0.05<\mathrm{p} \leq 0.10$. All analyses were conducted using the metafor package [31] in R [33]. 


\section{RESULTS}

\section{Characteristics of the database}

Table 1 provides a summary of 21 studies for Holstein dairy cows fed the supplemental fat containing saturated free FA. Five hundred and two Holstein dairy cows were included in the database. Twenty-nine comparisons (20 resulting from a FA group of a mixture of $\mathrm{C} 16: 0$ and $\mathrm{C} 18: 0,8$ from $\mathrm{C} 16: 0$, and 1 from $\mathrm{C} 18: 0)$ for variables of DMI, yields of milk fat and protein, and 30 comparisons (21 from a mixture of C16:0 and C18:0, 8 from C16:0, and 1 from C18:0) for other variables including milk yield, percentages of milk fat and protein, were obtained from both RBD and Latin square/crossover design studies. The supplemental fat was added to total mixed ration simply by replacing one ingredient (e.g., soyhull) at the same level of ration DM; or by doing so, the diet was then reformulated with multiple ingredients balancing for $\mathrm{CP}$; or the addition of the supplemental fat to control diet led all other ingredients consequently diluted. Mean, standard deviation, and minimal and maximal values for major selected variables in all studies were presented in Table 2 . The nutrient compositions of the experimental diets were notably variable among all studies, but no extremely high/low values of nutrients, especially total FA due to the supplemental fat, in the diets occurred.

\section{Dry matter intake and production responses}

Table 2. Mean and range of selected variables in the database

\begin{tabular}{lccccc}
\hline & Number & Mean & SD & Minimum & Maximum \\
\hline Diet & & & & & \\
CP (\% of DM) & 52 & 17.22 & 1.08 & 14.80 & 20.10 \\
NE (Mcal/kg of DM) & 33 & 1.67 & 0.11 & 1.42 & 1.89 \\
NDF (\% of DM) & 52 & 32.67 & 2.71 & 27.30 & 38.70 \\
ADF (\% of DM) & 23 & 22.04 & 2.41 & 19.16 & 28.80 \\
Starch (\% of DM) & 37 & 25.72 & 3.66 & 17.30 & 33.40 \\
Fatty acid (\% of DM) & 46 & 4.20 & 1.64 & 1.60 & 8.30 \\
DMI (kg/d) & 56 & 24.59 & 2.55 & 18.40 & 30.80 \\
Milk & & & & & \\
Yield (kg/d) & 58 & 38.23 & 6.55 & 26.40 & 51.20 \\
Fat (\%) & 58 & 3.54 & 0.44 & 2.84 & 4.89 \\
Fat yield (kg/d) & 56 & 1.356 & 0.318 & 0.881 & 2.310 \\
Protein (\%) & 58 & 3.03 & 0.14 & 2.78 & 3.43 \\
Protein yield (kg/d) & 56 & 1.161 & 0.194 & 0.787 & 1.630 \\
\hline SD standad deelation
\end{tabular}

SD, standard deviation; $C P$, crude protein; $D M$, dry matter; $\mathrm{NE}_{\text {, }}$, net energy for lactation NDF, neutral detergent fiber; ADF, acid detergent fiber; DMI, dry matter intake.

Compared with the control diet, supplementing $\leq 3.5 \%$ dietary DM of saturated free FA from added fat sources to dairy cows did not affect DMI (Table 3, Figure 1, overall; $\mathrm{MD}=0.061 \mathrm{~kg} / \mathrm{d}$; $95 \% \mathrm{CI}=-0.346$ to $0.469 ; \mathrm{p}=0.768$ ). The $\mathrm{DMI} \mathrm{MD}$ as a result of the supplemental fat was not different in studies between RBD and Latin square/crossover designs ( $\mathrm{p}=0.798)$. No evidence of significant heterogeneity (overall, $I^{2}=24.1 \% ; \mathrm{p}=0.166$ ) was

Table 3. Estimated mean difference and heterogeneity of DMI, milk yield, and milk compositions in Holstein cows supplemented with saturated free fatty acids

\begin{tabular}{|c|c|c|c|c|c|c|c|c|c|}
\hline & \multirow{2}{*}{$\begin{array}{c}\text { No. of } \\
\text { comparison }\end{array}$} & \multicolumn{4}{|c|}{ Mean difference } & \multicolumn{3}{|c|}{ Heterogeneity } & \multirow{2}{*}{$\begin{array}{c}\text { Study design } \\
\mathrm{p} \text {-value }\end{array}$} \\
\hline & & Estimate & SE & $95 \% \mathrm{Cl}$ & $p$-value & $I^{2}(\%)$ & $x^{2}(Q)$ & $\mathrm{p}$-value & \\
\hline \multicolumn{10}{|l|}{ DMI (kg/d) } \\
\hline Latin square/crossover & 15 & 0.015 & 0.328 & -0.629 to 0.658 & 0.965 & 33.2 & 20.9 & 0.104 & - \\
\hline Overall & 29 & 0.061 & 0.208 & -0.346 to 0.469 & 0.768 & 24.1 & 35.2 & 0.166 & 0.798 \\
\hline \multicolumn{10}{|l|}{ Milk yield (kg/d) } \\
\hline Overall & 30 & 1.684 & 0.258 & 1.178 to 2.191 & $<0.001$ & 0.0 & 19.7 & 0.903 & 0.660 \\
\hline \multicolumn{10}{|l|}{ Milk fat (\%) } \\
\hline RBD & 14 & 0.087 & 0.049 & -0.009 to 0.183 & 0.075 & 23.2 & 16.0 & 0.247 & - \\
\hline Latin square/crossover & 16 & 0.109 & 0.048 & 0.016 to 0.203 & 0.021 & 0.0 & 8.6 & 0.899 & - \\
\hline Overall & 30 & 0.095 & 0.032 & 0.031 to 0.158 & 0.003 & 4.1 & 24.8 & 0.687 & 0.627 \\
\hline \multicolumn{10}{|l|}{ Milk protein (\%) } \\
\hline RBD & 14 & -0.034 & 0.022 & -0.077 to 0.009 & 0.124 & 31.3 & 19.7 & 0.103 & - \\
\hline Latin square/crossover & 16 & --0.012 & 0.016 & -0.043 to 0.019 & 0.448 & 0.0 & 5.1 & 0.991 & - \\
\hline Overall & 30 & -0.022 & 0.012 & -0.045 to 0.001 & 0.063 & 0.0 & 25.7 & 0.639 & 0.344 \\
\hline \multicolumn{10}{|l|}{ Milk protein (kg/d) } \\
\hline RBD & 14 & 0.029 & 0.012 & 0.005 to 0.053 & 0.016 & 0.0 & 9.3 & 0.748 & - \\
\hline Latin square/crossover & 15 & 0.047 & 0.016 & 0.016 to 0.078 & 0.003 & 0.0 & 8.8 & 0.842 & - \\
\hline Overall & 29 & 0.036 & 0.010 & 0.017 to 0.054 & $<0.001$ & 0.0 & 19.0 & 0.899 & 0.361 \\
\hline
\end{tabular}

$\mathrm{DMI}$, dry matter intake; SE, standard error; $\mathrm{Cl}$, confidence interval; $\mathrm{RBD}$, randomized block design. 


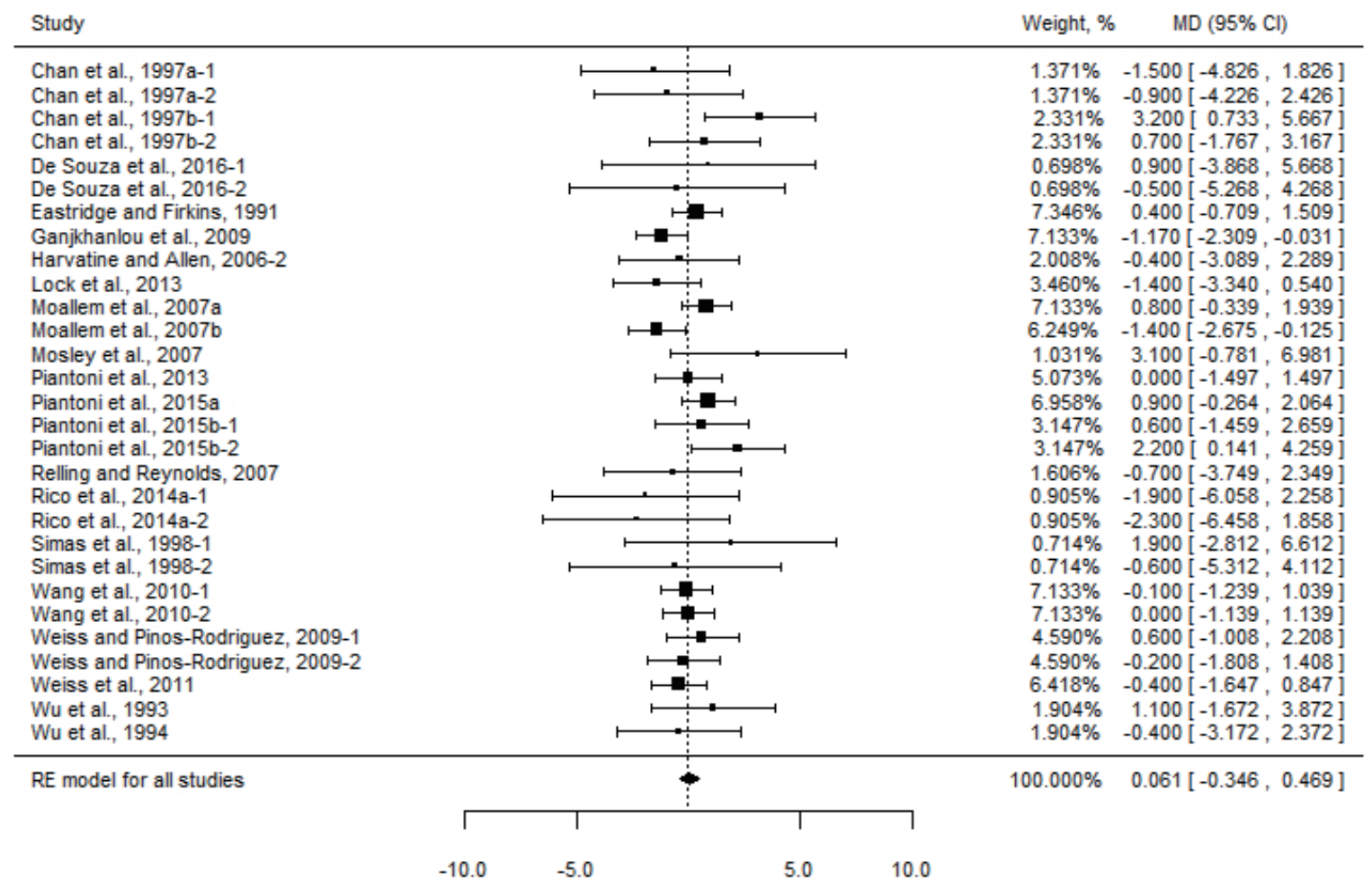

Figure 1. Forest plot of mean difference and their $95 \%$ confidence interval for dry matter intake $(\mathrm{kg} / \mathrm{d})$.

found (Table 3). Meta-regression analysis in all studies showed that $\mathrm{CP}$ content in control diet $(\mathrm{p}=0.020)$ positively impacted on DMI (Table 4). When supplementing saturated free FA as a mixture of C16:0 and C18:0 ( $\mathrm{p}=0.448)$, or as single FA containing C16:0 or C18:0 ( $\mathrm{p}=0.556$ ), DMI was unaffected (Table 5).
The supplemental fat increased milk yield (Table 3, Figure 2, overall; $\mathrm{MD}=1.684 \mathrm{~kg} / \mathrm{d} ; 95 \%$ CI: 1.178 to $2.191 ; \mathrm{p}<0.001$ ). Similar milk production improvements because of the supplemental fat, were observed in studies between RBD and Latin square/crossover designs $(\mathrm{p}=0.660)$. Moreover, the milk production data was

Table 4. Summary of significant meta-regression variables influencing the mean difference of DMI and milk production responses in dairy cows supplemented with saturated free fatty acids

\begin{tabular}{|c|c|c|c|c|}
\hline \multirow{2}{*}{ Variable } & \multicolumn{4}{|c|}{ Coefficient } \\
\hline & Estimate & SE & $95 \% \mathrm{Cl}$ & $\mathrm{p}$-value \\
\hline \multicolumn{5}{|l|}{$\mathrm{DMI}(\mathrm{kg} / \mathrm{d})$} \\
\hline Intercept & -9.605 & 4.142 & -17.722 to -1.488 & 0.020 \\
\hline CP (\% of DM, control diet) & 0.565 & 0.242 & 0.091 to 1.040 & 0.020 \\
\hline Milk yield (kg/d) & ND & - & - & - \\
\hline \multicolumn{5}{|l|}{ Milk fat (\%) } \\
\hline Intercept & -1.127 & 0.543 & -2.191 to -0.063 & 0.038 \\
\hline NDF (\% of DM, control diet) & 0.034 & 0.017 & 0.001 to 0.067 & 0.042 \\
\hline $\operatorname{DIM}^{1)}(\mathrm{d})$ & 0.001 & 0.001 & 0.0003 to 0.002 & 0.010 \\
\hline \multicolumn{5}{|l|}{ Milk fat (kg/d) } \\
\hline Intercept & -0.528 & 0.270 & -1.058 to 0.002 & 0.051 \\
\hline NDF (\% of DM, control diet) & 0.018 & 0.008 & 0.002 to 0.034 & 0.026 \\
\hline \multicolumn{5}{|l|}{ Milk protein (\%) } \\
\hline Intercept & 0.015 & 0.021 & -0.027 to 0.056 & 0.498 \\
\hline Length of supplementing (d) & -0.001 & 0.0004 & -0.002 to -0.0000 & 0.040 \\
\hline \multicolumn{5}{|l|}{ Milk protein (kg/d) } \\
\hline Intercept & -0.308 & 0.160 & -0.622 to 0.006 & 0.054 \\
\hline NDF (\% of DM, control diet) & 0.010 & 0.005 & 0.001 to 0.020 & 0.032 \\
\hline
\end{tabular}

$\mathrm{SE}$, standard error; $\mathrm{Cl}$, confidence interval; ND, not determined; DMI, dry matter intake; $\mathrm{CP}$, crude protein; DM, dry matter; NDF, neutral detergent fiber.

${ }^{1)}$ Day in milk at start of dietary treatments. 
Table 5. Estimated mean difference with $95 \% \mathrm{Cl}$ of DMI and milk yield and composition in Holstein cows supplemented with two groups of saturated free fatty acids

\begin{tabular}{|c|c|c|c|c|c|}
\hline & \multirow{2}{*}{ No. of comparison } & \multicolumn{4}{|c|}{ Mean difference } \\
\hline & & Estimate & SE & $95 \% \mathrm{Cl}$ & $p$-value \\
\hline \multicolumn{6}{|l|}{$\mathrm{DMI}(\mathrm{kg} / \mathrm{d})$} \\
\hline Single FA (C16:0 or C18:0) & 9 & -0.281 & 0.477 & -1.215 to 0.653 & 0.556 \\
\hline \multicolumn{6}{|l|}{ Milk yield (kg/d) } \\
\hline A mixture of $C 16: 0$ and $C 18: 0$ & 21 & 1.804 & 0.289 & 1.237 to 2.371 & $<0.001$ \\
\hline A mixture of $C 16: 0$ and $C 18: 0$ & 21 & 0.095 & 0.042 & 0.012 to 0.178 & 0.025 \\
\hline Single FA (C16:0 or C18:0) & 9 & 0.097 & 0.055 & -0.011 to 0.204 & 0.078 \\
\hline \multicolumn{6}{|l|}{ Milk fat $(\mathrm{kg} / \mathrm{d})$} \\
\hline A mixture of $C 16: 0$ and $C 18: 0$ & 20 & 0.075 & 0.019 & 0.038 to 0.113 & $<0.001$ \\
\hline Single FA (C16:0 or C18:0) & 9 & 0.066 & 0.024 & 0.020 to 0.113 & 0.006 \\
\hline A mixture of $C 16: 0$ and $C 18: 0$ & 20 & 0.036 & 0.011 & 0.015 to 0.058 & 0.001 \\
\hline Single FA (C16:0 or C18:0) & 9 & 0.034 & 0.019 & -0.003 to 0.071 & 0.070 \\
\hline
\end{tabular}

$\mathrm{SE}$, standard error; $\mathrm{Cl}$, confidence interval; DMI, dry matter intake; $\mathrm{FA}$, fatty acids.

highly homogeneous (overall, $I^{2}=0.0 \% ; \mathrm{p}=0.903$ ), regardless of different study designs (Table 3 ). No factors from proposed factor list were identified in meta-regression analysis that influenced the effect of the supplemental fat on milk production. When supplementing saturated free FA as a mixture of $\mathrm{C} 16: 0$ and C18:0 ( $\mathrm{p}<0.001)$, or as single FA containing C16:0 or C18:0 $(\mathrm{p}=0.035)$, milk yield increased (Table 5$)$.

Milk fat concentration was improved by supplementation of saturated free FA (Table 3, Figure 3, overall; $\mathrm{MD}=0.095 \%$; $95 \%$ CI: 0.031 to $0.158 \% ; p=0.003)$. Milk fat yield was greater in cows fed the supplemental fat (overall, $\mathrm{MD}=0.072 \mathrm{~kg} / \mathrm{d} ; 95 \% \mathrm{CI}: 0.045$ to $0.100 \mathrm{~kg} / \mathrm{d} ; \mathrm{p}<0.001)$. No differences were observed for milk

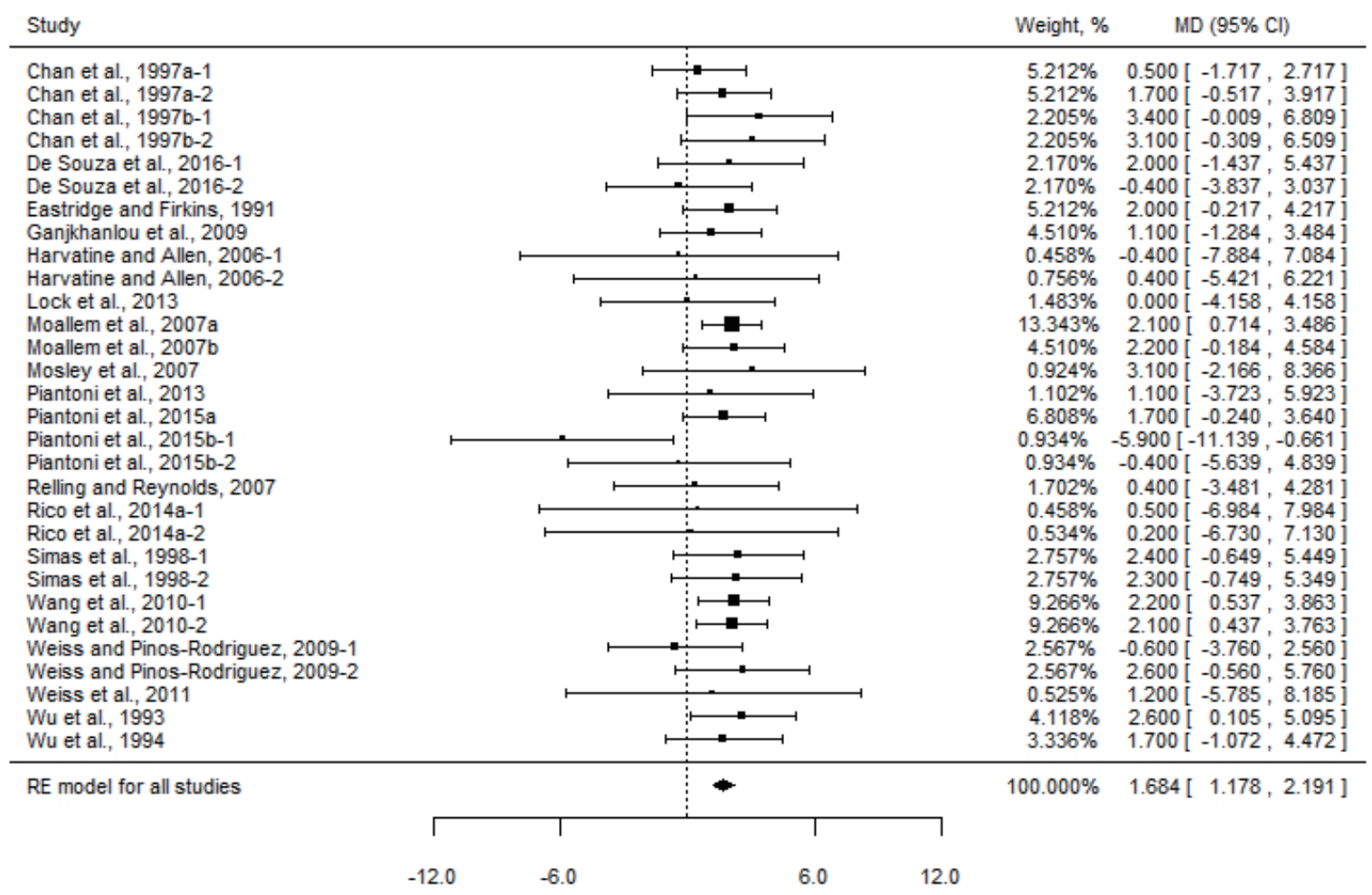

Figure 2. Forest plot of mean difference and their $95 \%$ confidence interval for milk yield (kg/d). 


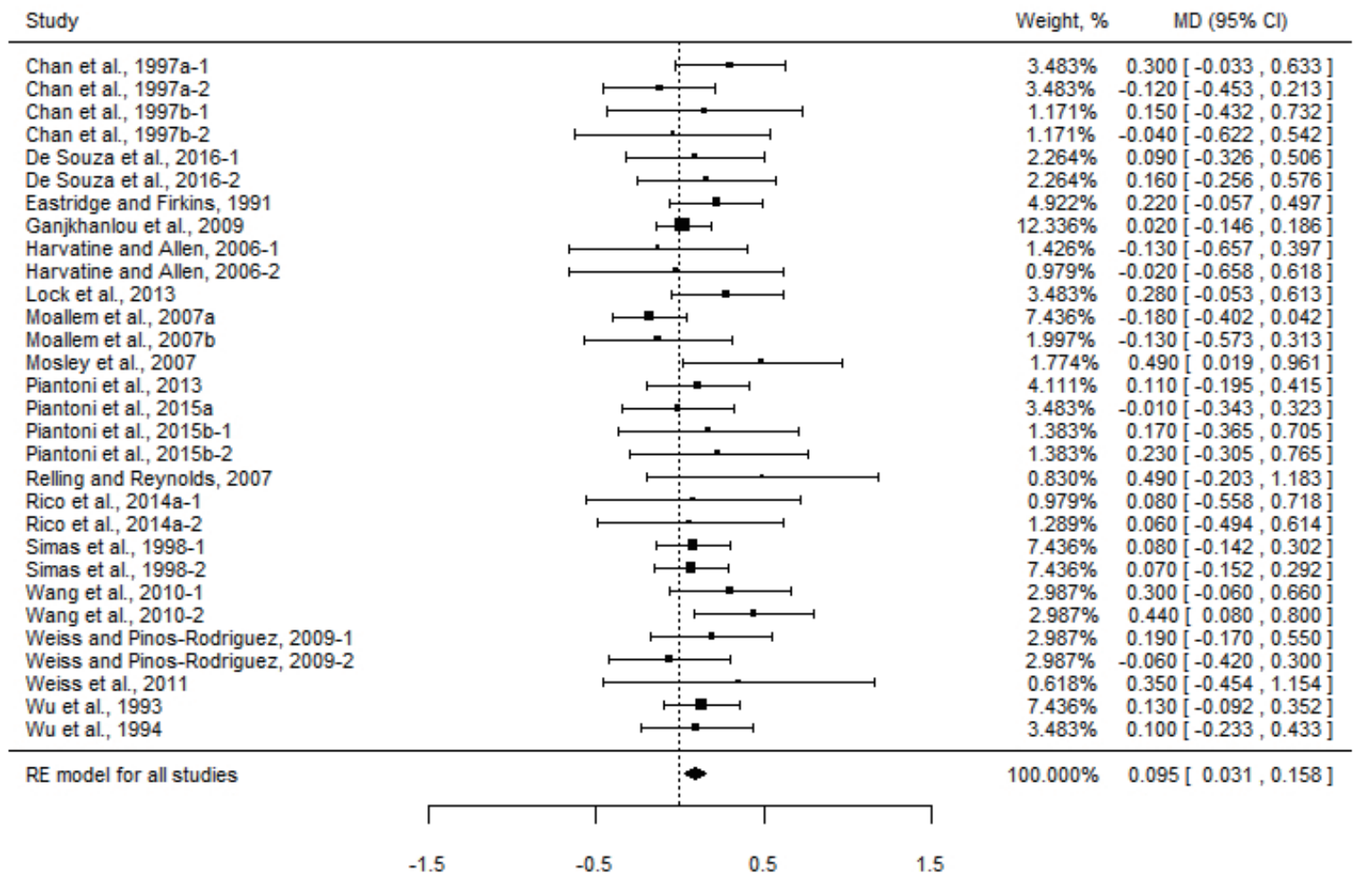

(A) Milk fat (\%)

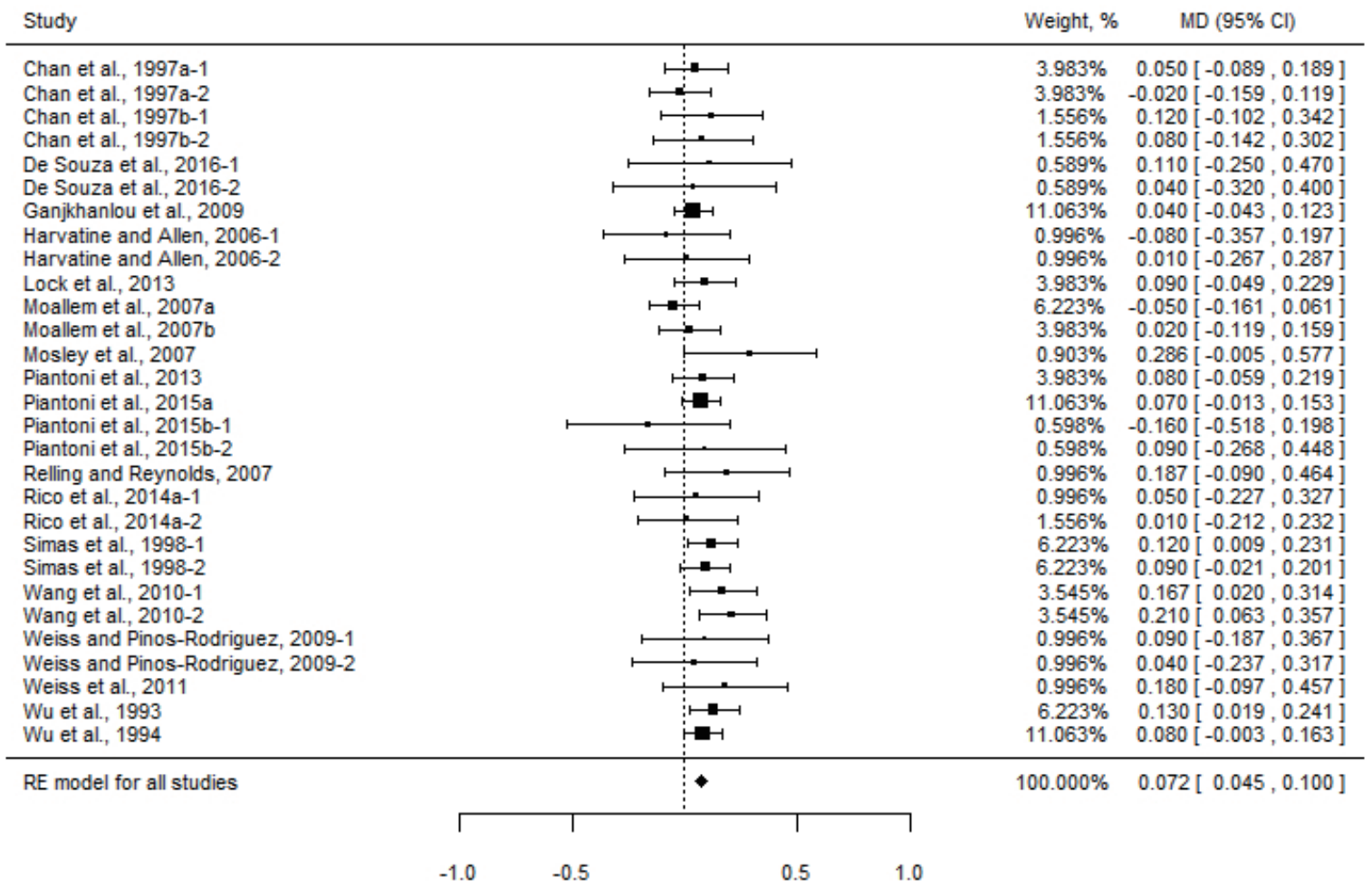

(B) Milk fat yield $(\mathrm{kg} / \mathrm{d})$

Figure 3. Forest plots of mean difference and their $95 \%$ confidence interval for milk fat (\%) and yield (kg/d).

fat concentration $(\mathrm{p}=0.627)$ and yield $(\mathrm{p}=0.876)$ in studies between RBD and Latin square/crossover designs. The milk fat concentration (overall, $I^{2}=4.1 \% ; \mathrm{p}=0.687$ ) and yield (overall, $\left.I^{2}=0.0 \% ; \mathrm{p}=0.805\right)$ responses to the supplemental fat were not 
heterogeneous (Table 3). Meta-regression analysis for the data including all studies showed that the NDF content in control diet $(\mathrm{p}=0.042)$ and day in milk at start of dietary treatments for dairy cows $(\mathrm{p}=0.010)$ had positive impact on milk fat concentration. In addition, NDF content in control diet $(\mathrm{p}=0.026)$ was positively associated with milk fat yield (Table 4). When supplementing saturated free FA as a mixture of C16:0 and C18:0, milk fat concentration $(\mathrm{p}=0.025)$ and yield $(\mathrm{p}<0.001)$ increased; while supplementing as single FA containing C16:0 or C18:0, milk fat concentration $(\mathrm{p}=0.078)$ tended to increase, but milk fat yield $(\mathrm{p}=0.006)$ increased (Table 5).

Milk protein concentration tended to decrease by supplementation of saturated free FA (Table 3, Figure 4, overall; MD $=-0.022 \%$; $95 \%$ CI: -0.045 to $0.001 \% ; \mathrm{p}=0.063)$. However, milk protein yield was greater in cows fed the supplemental fat (overall, $\mathrm{MD}=0.036 \mathrm{~kg} / \mathrm{d} ; 95 \% \mathrm{CI}: 0.017$ to $0.054 \mathrm{~kg} / \mathrm{d} ; \mathrm{p}<0.001)$. No differences were observed for milk protein concentration $(\mathrm{p}=$ 0.344 ) and yield ( $\mathrm{p}=0.361)$ in studies between RBD and Latin square/crossover designs. The milk protein concentration (overall, $I^{2}=0.0 \% ; \mathrm{p}=0.639$ ) and yield (overall, $I^{2}=0.0 \% ; \mathrm{p}=0.899$ ) responses to the supplemental fat were homogenous (Table 3 ). Meta-regression analysis in all studies showed that the length of feeding the supplemental fat $(p=0.040)$ had negative impact on milk protein concentration. Moreover, it was found that the NDF content in control diet $(\mathrm{p}=0.032)$ positively influenced the milk protein yield response to the supplemental fat (Table 4). When supplementing saturated free FA as a mixture of C16:0 and C18:0, milk protein concentration $(p=0.127)$ remained unchanged, but milk protein yield ( $\mathrm{p}=0.001)$ increased; while supplementing as single FA containing C16:0 or C18:0, milk protein concentration remained unchanged $(p=0.340)$, but milk protein yield $(\mathrm{p}=0.070)$ tended to increase (Table 5$)$.

\section{Publication bias}

Little evidence of publication bias were observed for DMI and milk fat yield (Figure 5). However, it was suggested from their respective funnel plots that there could possibly be a few values missing on the right sides for yields of milk and milk protein, but a few values missing on the left sides for percentages of milk fat and protein. The Egger's regression test for publication bias revealed a funnel plot symmetry for DMI, milk fat concentration and yield, milk protein concentration and yield ( $\mathrm{p} \geq 0.147$ for all of five variables), but a funnel plot asymmetric tendency for milk yield $(\mathrm{p}=0.063)$.

\section{DISCUSSION}

The database was developed that contained saturated free FA as added fat source to diets of Holstein dairy cows. The results from the current meta-analysis clearly demonstrated increases in yields of milk and milk components and unchanged DMI with supplementation of saturated free FA. Some of studies reported milk efficiency response to the supplemental fat. However, the reported milk efficiency in those studies was calculated or presented differently, thus we were unable to assemble milk efficiency data, and accurately estimate its MD. Nevertheless, given the responses of increased milk production and unchanged DMI to the supplemental fat in the meta-analysis, the addition of supplemental saturated free FA likely improved the efficiency of milk production. In addition, there were limited number of studies which reported changes of body weight and body condition score. MD for the changes of body weight and body condition score in response to the supplemental fat was not estimated.

Latin square/crossover design is commonly used in dairy nutrition studies, because it could statistically provide a more efficient comparison of dietary treatment effect than a parallel design. One of criticisms for such design however, is that there may be a carry-over effect of treatments across study periods, which could potentially distort the results obtained during the subsequent period, even though the effects of previous treatment could be minimized by an incorporation of "washout" period between treatments. Piantoni et al [3] showed that saturated fat supplementation interacted with dietary NDF content in the postpartum cows with carry-over effects in the following 42-days period when fed a common diet. Because of serious concern of the potential carry-over effect, Rabiee et al [6] excluded all Latin square/crossover design studies in their meta-analysis evaluating effects of fat additions to diets of dairy cattle. Nonetheless, the use of Latin square/crossover design in dairy nutrition study is built on the assumption that there is little/no carry-over effect of a treatment when proceeding from one period to the next. Given the popularity of Latin square/crossover design, dairy nutrition studies by such design should be combined with parallel design studies if a meta-analysis is conducted, a wealth of research information would otherwise, be wasteful. In the current metaanalysis, the effects of the supplemental fat have been evaluated in both RBD and Latin square/crossover design studies, and in all studies including RBD and Latin square/crossover designs. All variables responded in the same direction to the supplemental fat in either type of study designs. Furthermore, analysis from the mixed-effect model including study design as a fixed categorical effect did not reveal differences between RBD and Latin square/crossover design for all variables examined. It appears that findings from Latin square/crossover design studies can be incorporated into meta-analysis to evaluate effects of supplemental fat to cow diets.

The random-effects models examined heterogeneity of supplemental fat effect in terms of the Q test and $I^{2}$ statistics. All results indicated that the variations among the study-level of DMI, milk production, and milk composition responses to the supplemental fat were relatively small (Table 3). Thus, there was no clear evidence suggesting the effect of the supplemental fat on response variables was substantially associated with the variability among the studies. It is appropriate to use meta-regression to explore sources of 


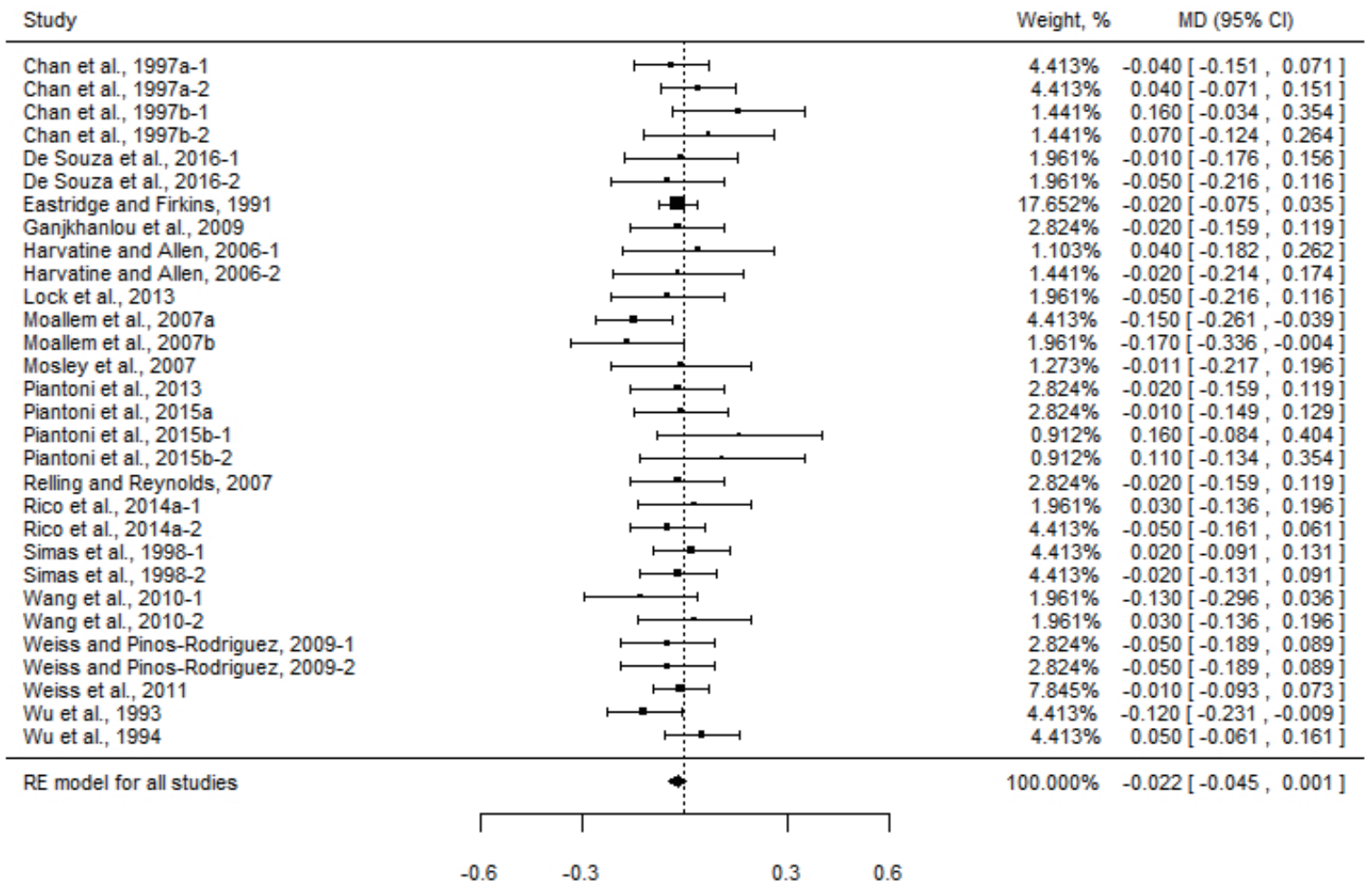

(A) Milk protein (\%)

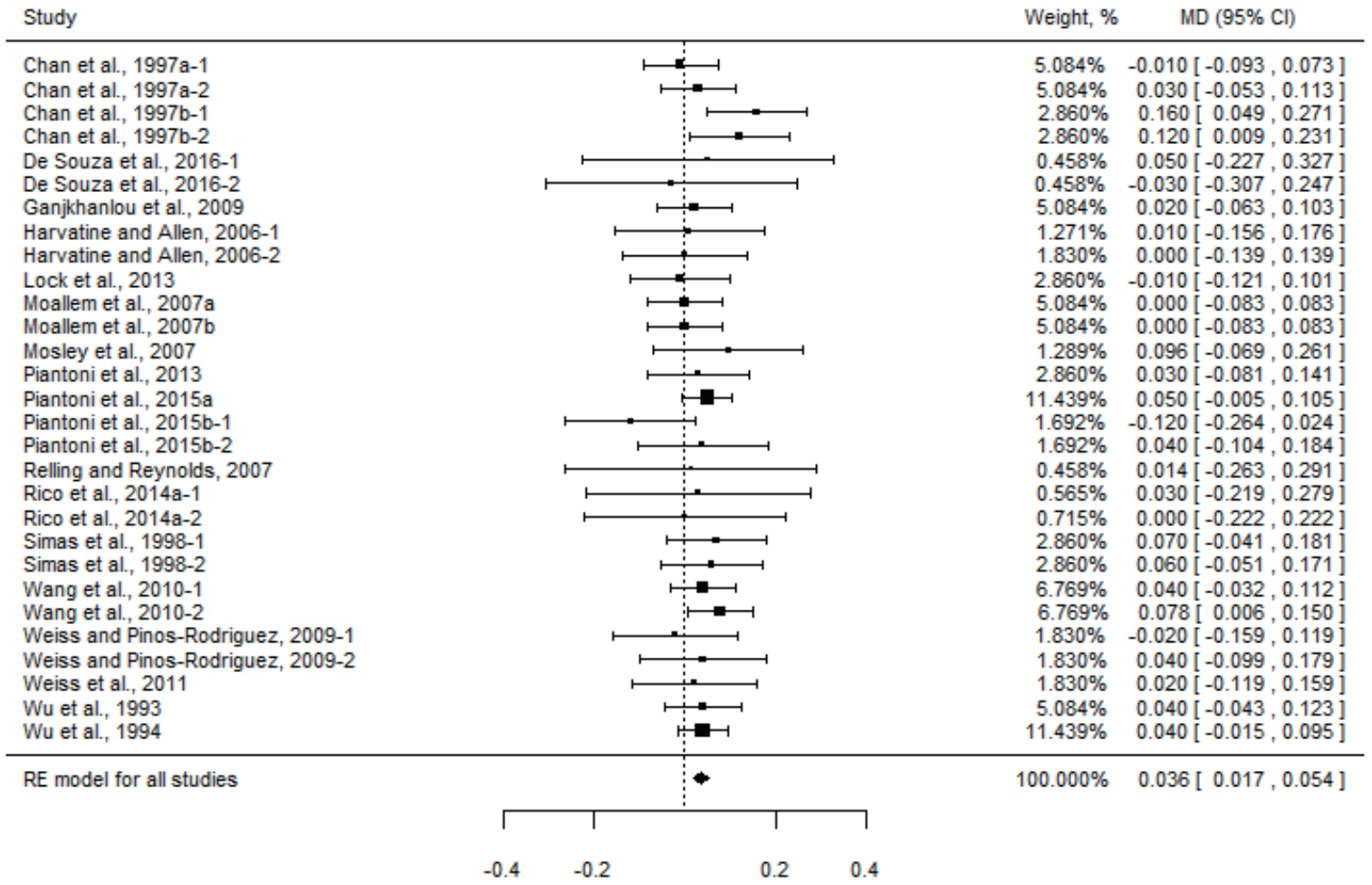

(B) Milk protein yield (kg/d)

Figure 4. Forest plots of mean difference and their $95 \%$ confidence interval for milk protein (\%) and yield (kg/d).

heterogeneity even though the test for heterogeneity is non-significant [34].
Saturated free FA was comprised of a mixture of C16:0 and C18:0, sole FA, i.e., C16:0 or C18:0 alone (Table 1). Metabolisms 

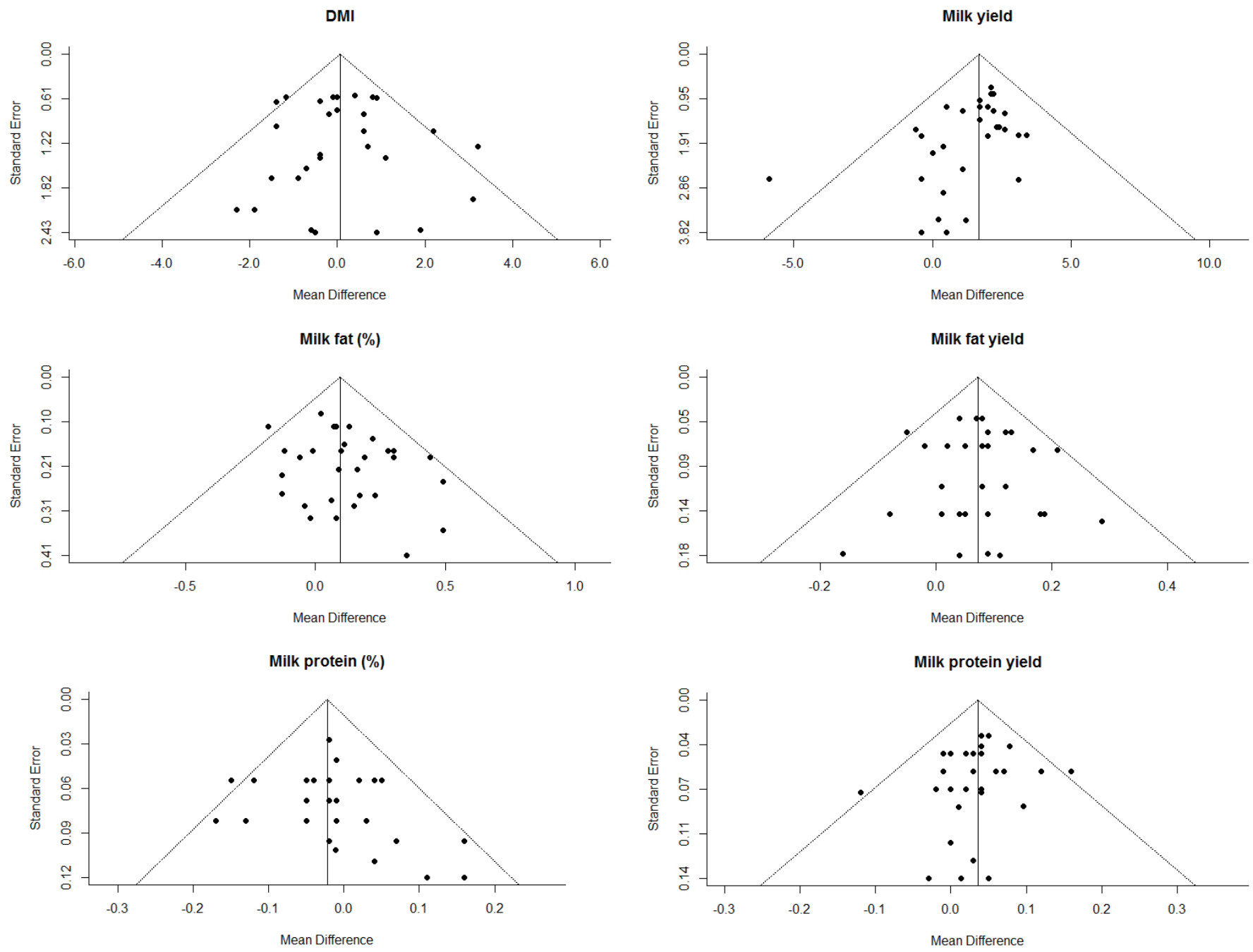

Figure 5. Funnel plots of DMI, milk yield, and milk composition responses in dairy cows from random-effects model.

of C16:0 and C18:0 in tissues of dairy cows are quite different, even though they are chemically similar - both are saturated and only differ by 2 carbon units [35]. It is reasonable to anticipate various milk production responses to the supplemental fat containing different saturated free FA, either alone or in combination. Rico et al [36] compared supplementing C16:0 and C18 in lactating cow diets ( $2 \%$ of DM), and found that there were no differences between C16:0 and C18:0 on DMI and milk yield, but C16:0 was more effective than C18:0 in improving milk fat and yield. Loften et al [35] speculated that, based on their literature review, better utilization may be achieved when supplementation of a mixture of both C16:0 and C18:0 in dairy cow diets than when fed alone. In the current meta-analysis, an effort was made via sub-group analysis method, to evaluate the effect of $2 \mathrm{FA}$ groups (a mixture of C16:0 and C18:0 vs single FA containing C16:0 or C18:0) on DMI and milk performance. It should be noted that only 9 comparisons occurred in single FA group. Because of limited studies available, single FA group as classified, could not be appropriately separated further into individual C16:0 and C18:0. Variances in single FA group indicated by SE (Table 5), for all response variables were higher compared to FA mixture group. Relatively high variances, likely due to small number of comparisons or two different FA contained in single FA group, were indicative of lacking precision or accuracy. The results achieved should thus be interpreted with caution. In addition, the data between two FA groups was very unbalanced, analysis using mixed-effects models by including 2 FA groups as a fixed categorical effect, was not conducted to examine the influence of FA group (a mixture vs single FA). More studies are needed to fully explore variations of responses of DMI and milk production to different saturated free FA containing either $\mathrm{C} 16: 0$ or C18:0 alone, or a mixture of both C16:0 and C18:0.

The meta-regression analysis indicated that DMI increased with increased CP content in control diet. Allen [37] found that response in DMI was positively related to diet $\mathrm{CP}$ content in the regression analysis of a data set developed from studies reported in the literature.

As indicated by both Egger's regression test and funnel plot, 
publication bias might exist for milk yield. In general, studies with significant, positive results are more likely to be published in the case of interventions with a commercial value, in comparison to studies with nonsignificant, negative results [32]. If there were missing studies for milk yield, the missing studies indicated by funnel plots for percentages of milk fat and protein should be reflected in funnel plots at the same direction. Moreover, little or no obvious evidence of publication bias was found for other response variables such as DMI and milk fat yield, derived from the database including all of the same studies. We concluded that there was no substantial publication bias in the current meta-analysis.

\section{CONCLUSION}

The results of the current meta-analysis showed supplementing saturated free FA at $\leq 3.5 \%$ of diet DM in diets of Holstein dairy cows from commercially available fat sources increased milk yield, and yields of milk fat and protein, while DMI remained unchanged. As indicated by heterogeneity test, no substantial heterogeneity occurred across all studies for DMI and milk production responses to the supplemental fat. Higher yields of milk and milk components combined with unchanged DMI, suggested the supplemental fat likely improved the efficiency of milk production. More studies need to be conducted to assess the variation of production responses to different saturated free FA, either C16:0 or C18:0 alone, or in combination with potentially optimal ratio, when supplemented in dairy cow diets.

\section{CONFLICT OF INTEREST}

We certify that there is no conflict of interest with any financial organization regarding the material discussed in the manuscript.

\section{REFERENCES}

1. Lock AL, Preseault CL, Rico JE, DeL KE, Allen MS. Feeding a C16:0enriched fat supplement increased the yield of milk fat and improved conversion of feed to milk. J Dairy Sci 2013;96:6650-9.

2. Piantoni P, Lock AL, Allen MS. Milk production responses to dietary stearic acid vary by production level in dairy cattle. J Dairy Sci 2015;98: 1938-49.

3. Piantoni P, Lock AL, Allen MS. Saturated fat supplementation interacts with dietary forage neutral detergent fiber content during the immediate postpartum and carryover periods in Holstein cows: production responses and digestibility of nutrients. J Dairy Sci 2015;98:3309-22.

4. De Souza J, Preseault CL, Lock AL. Lactational responses to palmitic acid supplementation when replacing soyhulls or dry ground corn. J Dairy Sci 2016;99:1945-50.

5. Onetti SG, Grummer RR. Response of lactating cows to three supplemental fat sources as affected by forage in the diet and stage of lactation: a meta-analysis of literature. Anim Feed Sci Technol 2004;115:65-82.
6. Rabiee AR, Breinhild K, Scott W, et al. Effect of fat additions to diets of dairy cattle on milk production and components: A meta-analysis and meta-regression. J Dairy Sci 2012;95:3225-47.

7. Boerman JP, Lock AL. Feed intake and production responses of lactating dairy cows when commercially available fat supplements are included in diets: a meta-analysis. J Dairy Sci 2014;97(E-Suppl. 1): 319.

8. NRC. Nutrient requirements of dairy cattle. 7th revised ed. Washington, DC: National Academy Press; 2001.

9. Eastridge ML, Firkins JL. Feeding hydrogenated fatty acids and triglycerides to lactating dairy cows. J Dairy Sci 1991;74:2610-6.

10. Wu Z, Huber JT, Sleiman FT, et al. Effect of three supplemental fat sources on lactation and digestion in dairy cows. J Dairy Sci 1993;76: 3562-70.

11. Wu Z, Huber JT, Chan SC, et al. Effect of source and amount of supplemental fat on lactation and digestion in cows. J Dairy Sci 1994;77: 1644-51.

12. Chan SC, Huber JT, Chen KH, Simas JM, Wu Z. Effects of ruminally inert fat and evaporative cooling on dairy cows in hot environmental temperatures. J Dairy Sci 1997;80:1172-8.

13. Chan SC, Huber JT, Theurer CB, et al. Effects of supplemental fat and protein source on ruminal fermentation and nutrient flow to the duodenum in dairy cows. J Dairy Sci 1997;80:152-9.

14. Simas JM, Huber JT, Theurer CB, et al. Influence of sorghum grain processing on performance and nutrient digestibilities in dairy cows fed varying concentrations of fat. J Dairy Sci 1998;81:1966-71.

15. Harvatine KJ, Allen MS. Effects of fatty acid supplements on milk yield and energy balance of lactating dairy cows. J Dairy Sci 2006;89: 1081-91.

16. Moallem U, Katz M, Arieli A, Lehrer H. Effects of peripartum propylene glycol or fats differing in fatty acid profiles on feed intake, production, and plasma metabolites in dairy cows. J Dairy Sci 2007;90: 3846-56.

17. Moallem U, Katz M, Lehrer H, Livshitz L, Yakoby S. Role of peripartum dietary propylene glycol or protected fats on metabolism and early postpartum ovarian follicles. J Dairy Sci 2007;90:1243-54.

18. Mosley SA, Mosley EE, Hatch B, et al. Effect of varying levels of fatty acids from palm oil on feed intake and milk production in Holstein cows. J Dairy Sci 2007;90:987-93.

19. Relling AE, Reynolds CK. Feeding rumen-inert fats differing in their degree of saturation decreases intake and increases plasma concentrations of gut peptides in lactating dairy cows. J Dairy Sci 2007;90: 1506-15.

20. Ganjkhanlou M, Rezayazdi K, Ghorbani GR, et al. Effects of protected fat supplements on production of early lactation Holstein cows. Anim Feed Sci Technol 2009;154:276-83.

21. Weiss WP, Pinos-Rodríguez JM. Production responses of dairy cows when fed supplemental fat in low- and high-forage diets. J Dairy Sci 2009;92:6144-55.

22. Weiss WP, Pinos-Rodríguez JM, Wyatt DJ. The value of different fat supplements as sources of digestible energy for lactating dairy cows. J Dairy Sci 2011;94:931-9. 
23. Wang JP, Bu DP, Wang JQ, et al. Effect of saturated fatty acid supplementation on production and metabolism indices in heat-stressed mid-lactation dairy cows. J Dairy Sci 2010;93:4121-7.

24. Rico DE, Ying Y, Harvating KJ. Effect of a high-palmitic acid fat supplement on milk production and apparent total-tract digestibility in high- and low-milk yield dairy cows. J Dairy Sci 2014;97:3739-51.

25. Piantoni P, Lock AL, Allen MS. Palmitic acid increased yields of milk and milk fat and nutrient digestibility across production level of lactating cows. J Dairy Sci 2013;96:7143-54.

26. Elliott JP, Drackley JK, Fahey GC Jr, Shanks RD. Utilization of supplemental fat by dairy cows fed diets varying in content of nonstructural carbohydrates. J Dairy Sci 1995;78:1512-25.

27. Warntjes JL, Robinson PH, Galo E, DePeters EJ, Howes D. Effects of feeding supplemental palmitic acid (C16:0) on performance and milk fatty acid profile of lactating dairy cows under summer heat. Anim Feed Sci Technol 2008;140:241-57.

28. Firkins JL, Eastridge ML, St-Pierre NR, Noftsger SM. Effects of grain variability and processing on starch utilization by lactating dairy cattle. J Anim Sci 2001;79(E. Suppl.):E218-38.

29. Cummings P. Meta-analysis based on standardized effects is unreliable.
Arch Pediatr Adolesc Med 2004;158:595-7.

30. Cummings P. Arguments for and against standardized mean differences (effect sizes). Arch Pediatr Adolesc Med 2011;165:592-6.

31. Viechtbauer W. Conducting meta-analyses in $\mathrm{R}$ with the metafor package. J Stat Softw 2010;36:1-48.

32. Lean IJ, Rabiee AR, Duffield TF, Dohoo IR. Invited review: use of metaanalysis in animal health and reproduction: methods and applications. J Dairy Sci 2009;92:3545-65.

33. R Core Team. R: A language and environment for statistical computing. Vienna, Austria: R Foundation for Statistical Computing. Version 3.1.3, 2015; Available from: https://www.r-project.org

34. Thompson SG, Higgins JPT. How should meta-regression analyses be undertaken and interpreted? Stat Med 2002;21:1559-73.

35. Loften JR, Linn JG, Drackley JK, et al. Palmitic and stearic acid metabolism in lactating dairy cows. J Dairy Sci 2014;97:4661-74.

36. Rico JE, Allen MS, Lock AL. Compared with stearic acid, palmitic acid increased the yield of milk fat and improved feed efficiency across production level of cows. J Dairy Sci 2014;97:1057-66.

37. Allen MS. Effects of diet on short-term regulation of feed intake by lactating dairy cattle. J Dairy Sci 2000;83:1598-624. 